Received: February $25^{\text {th }}, 2018 \quad$ Revised: March $13^{\text {th }}, 2018 \quad$ Accepted: March $23^{\text {th }} 2018$

\title{
A Supply Chain Risk Management for Dadih Product by Pricing Optimization
}

\author{
D. Delfitriani ${ }^{1}$, Taufik Djatna ${ }^{2}$, Ma'ruf Pambudi Nurwantara ${ }^{3}$ \\ ${ }^{1}$ Agroindustrial Technology Program Graduate School of Bogor Agricultural University, Indonesia \\ ${ }^{2,3}$ Agriculture Industrial Technology Department, Brawijaya University, Indonesia
}

\begin{abstract}
Risk mitigation by using risk-sharing approach is a method to minimize risk on supply chain management. In this case, the pricing optimization is needed to maximize and to balance the profit of each stakeholder on its sphere. This paper focused on Dadih product supply chain risk modeling which has three objectives: (1) to identify, (2) to evaluate the risk of each sphere along Dadih product supply chain, and (3) to build a supply chain risk management model for Dadih product by pricing optimization. The model is started by risk identification which showed that there were 52 risks along the whole chain. Then these risks were evaluated by using risk index measurement which showed that the dairy farmer sphere has the highest risk proportion on the whole chain. Finally, the optimum prices were obtained by using a risk-sharing model which is generated from the result of risk evaluation and the result of stakeholder efficiency measurement by using DEA method. We also found that the prices fluctuation among the DMU became smoothly after the optimization which occurred as a result of risk distribution along the chain.
\end{abstract}

Keywords: Dadih product; DEA; pricing optimization; risk sharing model; supply chain risk management

Author Correspondence:

D. Delfitriani

Agroindustrial Technology Program Graduate School of Bogor Agricultural University, Bogor, Indonesia E-mail: delfitri70@gmail.com.

\section{Introduction}

The risk is the possibility of an event that resulted in a loss when the event occurred during a specific period. Supply chain activities are inseparable from risks at every level as a result of the uncertainty of demand, supply, or internal company [1]. The risks also must be controlled to avoid the problem of material supply that affects the financial loss of the company [2]. These can be managed by identifying, measuring, and managing those risks [3]. At the risk factors being competitive position [4]. While government policy is very necessary with a very high-risk value

In this paper focus on the risk management of supply chain of the dadih product. Dadih is typical Indonesian traditional fermented milk which is produced and consumed by West Sumatran Minangkabau ethnic group. Dadih is also indicated as one of the essential traditional foods of Minangkabau culture [5]. The development of buffalo cattle population as the primary raw material of dadih production which decreased in quantity and geographic impact on the decrease of the dadih production in West Sumatra. For instance, in 2015, the West Sumatera buffalo population was 121939 heads, while the population in 2009, 202.997 heads [6]. The production capacity of the buffalo milk business is relatively low, $1,5-2,5$; liters per a day. It had no economic value if compared with cow dairy production reaching 20 liters per day [7]. The condition threatens the existence of the dadih as a product of geographical indication. One effort in ensuring its existence is by replacing the primary raw material into cow's milk. Consequently, the dadih processing would have to be modified by the addition 
of probiotic starter to produce cow's milk dadih with similar characteristics to buffalo milk dadih [8].

Technological support and marketing management is needed to expand the market for the dadih product. Besides, the number of competing products on the market which are fermented dairy products that have been using advanced technology to make supply chain risk management of dadih products is essential to improve the competitive advantage of the product. The supply chain of dadih product in West Sumatra consists of several networks ranging from beef suppliers, dairy farmers, dairy collectors, dadih industry, retailers, and consumers. The existence of some networks involved in the supply chain of dadih products certainly raises the risk on every supply chain network. Implementation of supply chain risk management needs to be done systematically to identify and analyze risks associated with the supply chain. The process of identifying risks in the supply chain of dadih products is used to provide information on supply chain conditions and risk evaluation along with the mitigation design of each supply chain network.

Currently, the producers of dadih cannot determine the selling price because the price was done and controlled by intermediary traders. Distribution of profit that is not balanced with the operational costs of the offender becomes the factor causing the difficulty of determining the selling price of the product. The imbalance factor of profit distribution triggers the occurrence of risk on quality and quality standard, quantity of supply and price of the dadih product. The complexity of dadih product development problems in West Sumatra is 1) lack of volume of raw material supply in upstream supply chain, 2) lack of proper coordination on every supply chain actor to solve problems along supply lines, 3 ) one of the supply chain of dadih products, 4) the producers of butter cannot determine the selling price, 5) the absence of proper supply chain design for dadih products in West Sumatra.

One aspect of supply chain management is value added. Improving the performance of supply chain management will have a positive impact on the added value of each supply chain element. The identification of added value in supply chain management can be implemented in the production of dadih products to find out the added value obtained by supply chain level. The added value of dadih products is directly proportional to the amount of income to be received. Based on these motivations, it can be proposed supply chain risk management for risk mitigation and added value of dadih products.

The purpose of this paper is to identify risk factors from each level of the way supply chain, to evaluate the risks at each level of the supply chain and to formulate the form of risk balancing supply chain of dadih products with the risk distribution model approach. This paper consists of 4 parts, the introduction to part 1, the method in part 2, the discussion in Section 3, and the conclusion in Section 4.

\section{Material and Methods}

The identification of the dadih supply chain risk began with identifying the number of stakeholders $\left(\mathrm{X}_{\mathrm{i}}\right)$ involved in the supply chain of dadih, where $(\mathrm{i}=1,2, \ldots, \mathrm{n})$. Each network has several risks that may cause the failure of the supply product $\left(\mathrm{P}_{\mathrm{i}} \mathrm{X}\right)$. It is a critical stage in the model. The model will be more accurate in representing the real world when the data is more detailed.

At this stage, the proportion of the added value of actors ( $\beta_{x}$ ) on the whole chain using the Hayami method template and the risk consequence value of each supply chain actor $\left(\alpha_{\mathrm{x}}\right)$ is calculated. The added value describes the rewards for labor, capital, and management that are mathematically stated as follows:

$$
\beta_{x}=f\{K, B, T, U, H, h, L\}
$$


Explanation:

$\mathrm{K}=$ production capacity

$\mathrm{B}=$ raw materials used

$\mathrm{T}$ = labour used

$\mathrm{U}=$ wages of labour

$\mathrm{H}=$ output price

$\mathrm{h}=$ raw material price

$\mathrm{L}=$ other input value

The risk index value is at a value between zero and one. Consequence values can be classified as vital, required, required, and desirable as in Table 1.

Table 1

Value of risk consequences

\begin{tabular}{ccc}
\hline Consequences & Explanation & $\mathrm{A}$ \\
\hline Vital & Irreplaceable & 1 \\
Needed & Not easily replaced & 0.6 \\
Required & Easy to replace & 0.3 \\
Desired & Easy to replace & 0.1 \\
\hline
\end{tabular}

Then, based on the information, calculated risk index on each network using Risk Index formula as follows:

$$
R I_{x}=\alpha_{x} \beta_{x}\left(1-\prod_{i=1}^{n}\left(1-\left(P_{i} X\right)\right)\right.
$$

Explanation:

$R_{i x}=$ Risk index of the X-stakeholder

$\alpha_{x}=$ The consequence of the stakeholder $\mathrm{x}$ that the offender must bear when the product fails to supply.

$\beta_{x}=$ The percentage of added value provided by the $\mathrm{x}$-stakeholder

$x=$ The stakeholder

$P_{i} X=$ The possibility of the i-component of the $\mathrm{x}$-stakeholder

Measuring the performance of actors from the supply chain of dadih products

According to [1], a performance measurement system is needed to 1) monitor and control 2) communicate organizational goals to functions in the supply chain; 3) know where the position of an organization is relative to competitors and to the objectives to be achieved; and 4) determine the direction of improvement to create competitive advantage.

Measurement of performance of supply chain actors is done using Data Envelopment Analysis (DEA) method approach. DEA method is assigned as a tool in determining supply chain performance due to several factors ie: 
1. DEA able to work simultaneously and continuously through Benchmarking process to get efficiency value of each supply chain actor.

2. Selection of performance parameters within the risk distribution model aims to obtain output in the form of increased profit of supply chain actors who work competitively when applied. DEA as a performance measurement method can accommodate one of the objectives of this model so that there is no limit to increase the value of efficiency variables between one actor with another.

3. The working principle of DEA that is simultaneous and sustainable can increase the total profit of supply chain actors as a whole, specifically to the actors who will distribute advantage due to the implementation of the model.

The determination of the efficiency value of the Decision-Making Unit (DMU) of each unit in measurement $\left({ }^{\theta_{i}}\right)$ in performing operational activities is determined from the ratio of inputs $\left({ }^{I_{i j}}\right)$ and outputs $\left({ }^{O_{i j}}\right)$ when compared to other DMUs The efficiency value of a unit of measurement depends on the output and input value and weight of the value the output variable $\left({ }^{w_{i j}}\right)$ and the importance of the input variable ( ${ }^{V i j}$ ) of DMU. The following formulation of the DEA is shown as follows:

$$
\theta_{j}=\frac{\sum_{j=1}^{n_{0}} o_{i j} w_{i j}}{\sum_{j=1}^{n_{0}} I_{i j} v_{i j}}
$$

At each measurement process, the unit can not determine the weight against itself which will cause the efficiency of other units including the unit exceeds 100\%. It is impossible for each unit to achieve an efficiency of more than $100 \%$ based on the weighting of each unit's measurements. Therefore, each unit of measurement resulting in an accumulation of multiplied weights with output should not exceed rather than the accumulation of multiplication of weights with inputs. The formulation can be seen in the equation:

The equations are presented as an illustration. Equations are centered and numbered consecutively starting from 1 as follows:

$$
\sum_{j=1}^{n_{0}} o_{i j} w_{i j} \leq \sum_{j=1}^{n_{0}} I_{i j} v_{i j}
$$

To prevent the solution beyond the desired limit the cumulative multiplication weights with the input of the unit of measurement equals 1 according to the equation:

$$
\sum_{j=1}^{n_{0}} I_{i j} v_{i j}=1
$$

DEA Objective function:

$$
\max \sum_{\mathrm{j}=\mathrm{i}}^{\mathrm{n}_{0}} \mathrm{O}_{\mathrm{ij}} \mathrm{W}_{\mathrm{ij}}
$$


Subject to:

$$
\begin{aligned}
& \sum_{j=i}^{n_{0}} I_{i j} V_{i j}-\sum_{j=i}^{n_{0}} O_{i j} W_{i j} \leq 0 \\
& \sum_{j=i}^{n_{0}} I_{i j} V_{i j}=1 \\
& V_{i j}, W_{i j} \geq 0
\end{aligned}
$$

The risk mitigation process through the risk distribution approach is one part of the risk management approach to supply chain management [9] [10]. The risk distribution model is used to balance the profit of each stakeholder. In this model, the price mechanism is split into two components: fixed price $\left(\mathrm{F}_{\mathrm{yi}}\right)$ and incentive (I). The element has the same proportion in the price mechanism that is $50 \%$ of the total price allocated to each stakeholder while the other $50 \%$ is allocated as the performance incentive. In other words, the higher the performance of stakeholders the incentives are obtained as high prize remain. The formulation of the price mechanism can be seen as follows:

$$
F P_{y i}=\frac{\left(W R_{i} F_{y}\right)}{2}+\left(\frac{W R_{i} F_{y}}{2}-\left(1-\theta_{y i}\right)\left(\frac{W R_{i} F_{y}}{2}\right)\right)
$$

Constraint function:

$$
\begin{aligned}
& W R_{i}<1 \\
& \theta>1 \\
& \sum_{j=i}^{n_{0}} O_{i j} w_{i j}-\sum_{j=i}^{n_{0}} I_{i j} v_{i j} \leq 0 \\
& \sum_{j=i}^{n_{0}} I_{i j} v_{i j}=1 \\
& w_{i j} v_{i j} \geq 0 \\
& \rho<1
\end{aligned}
$$

Where:

$$
\begin{aligned}
F P_{y i} & =\text { The optimum price of unit } \mathrm{i} \text { in region } \mathrm{y} \\
W R_{i} & =\text { The weight of the } \mathrm{i} \text {-unit risk } \\
F_{y} & =\text { Fix payment of the } \mathrm{i} \text {-unit of the } \mathrm{y} \text { distribution } \\
\theta_{y i} & =\text { Performance value of unit } \mathrm{i} \text { in region } \mathrm{y} \\
\rho & =\text { A coefficient of risk aversion of supply chain actors } \\
O_{i j} & =\text { The output variable } \mathrm{j} \text { of the } \mathrm{i} \text { unit } \\
w_{i j} & =\text { The output weight } \mathrm{j} \text { of the } \mathrm{i} \text { unit } \\
I_{i j} & =\text { The input variable to the } \mathrm{j} \text { of the } \mathrm{i} \text {-unit } \\
v_{i j} & =\text { The input weight } \mathrm{j} \text { of the } \mathrm{i} \text {-unit }
\end{aligned}
$$

\section{Results and Discussion}

\subsection{Identification of supply chain risk of dadih products}

\section{Product characteristics}

The dadih is the original fermented milk from the West Sumatera region with a rather thick 
consistency resembling tofu. The dadih is traditionally made from buffalo milk placed in bamboo and covered with diluted banana leaves and left to ferment naturally at room temperature for 48 hours [11]. Fermentation occurs by relying on microbes present in nature or without the use of additional starter [12]. Microbes isolated from the dadih are estimated to come from banana leaves as cover, buffalo milk, and bamboo at the time of preparation.

The dadih is potential to be developed into a probiotic product as the functional food to be enjoyed by the wider community. Probiotics are living microbes attached to the intestinal wall, beneficial to host health [13] or dietary supplements containing pure cultures or mixtures of living microbes that benefit the host by maintaining an indigenous balance of microbes in the digestive tract. The dadih which are of good quality is white, consistency resembles yogurt and has a distinctive aroma of sour milk. The composition of dadih nutrition is water content $(82.10 \%)$, protein $(6.99 \%)$, fat $(8.08 \%)$, acidity $\left(130.5^{\circ} \mathrm{D}\right)$ and $\mathrm{pH} 4.99$.

\section{Characteristics of raw materials}

Cow milk processing is intended to diversify cow's milk into food in various forms. In addition to avoiding cow's milk does not become wasteful or wasted. As we know that pure cow's milk is only able to survive in less than 24 hours. Through the deadline, if you can not use it, then the milk will be wasted and cause losses that are not least in value. Diversification of cow's milk can be managed in the home industry or large-scale, and of course for both of this required equipment that all practical and modern, in order to obtain maximum results.

As a food/beverage milk has high nutritional value because it contains chemical elements needed by the body such as Calcium, Phosphor, Vitamin A, Vitamin B and Riboflavin high. Its easily digestible composition with high levels of protein, minerals, and vitamins makes milk a source of soft food that can be regulated in fat levels, to meet the desires and tastes of consumers.

\section{Analysis of dairy cows}

The supply chain of dadih products at the level of cattle breeders refers more to dairy farms of the general public in West Sumatra; this is because most cattle farms are traded for beef cattle. The population of dairy cattle in Indonesia is still relatively low compared to other livestock populations. Dairy cows are at the second lowest position of all types of livestock in Indonesia. In 2010 to 2014 the average number of dairy cows is 525 (thousand heads). The most abundant population of livestock species is broiler livestock with an average population of 1247066 (thousand heads).

The dairy cow is a cow that can produce milk in large quantities. Dairy farming is one part of the livestock sub-sector that needs to be considered. Given the ecological, geographic and soil fertility conditions of some areas in Indonesia, then actually the opportunity to develop the dairy industry is quite good. Also, the production of dairy cows, ie milk is a product that is always needed by the community.

The color of the milk may change from one color to another, depending on the livestock, the type of feed, the amount of fat, solids and color-forming materials. The color of the milk ranges from bluish white to golden yellow. The white color of milk is the result of the dispersion of light reflected by the fat globules and colloidal particles of casein and calcium phosphate. The yellow color is due to fat and carotene being soluble. When the fat is taken from milk then the milk will show a bluish color. Milk tastes slightly sweet, caused by lactose, while the salty taste comes from chlorides, citrates, and other mineral salts. The smell of milk is easily changed from the delicious smell to the unpleasant smell. This 
odor is influenced by the fatty nature of milk that easily absorbs the smell around it. Similarly, cattle feed ingredients can change the smell of milk.

Breast milk has a higher density than water that is 1,031 . Like BJ then the viscosity of milk is higher than water. The viscosity of the milk usually ranges from 1.5 to $2.0 \mathrm{cP}$. In the milk codex, it is stated that the freezing point of milk is $-0.5000 \mathrm{C}$. However for Indonesia has changed to $-0.5200 \mathrm{C}$. Dairy contains ingredients/substances which in totality can be digested, absorbed and utilized correctly or $100 \%$. Therefore milk is declared very good as a food ingredient. No more good food animal was especially vegetable with the same power with milk.

The supply chain network of dadih products at the collecting level consists of cattle milk traders in small and large parties. Usually, the gathering merchants (1) go to the homes of residents who have dairy cows and offer price agreements to the owner of the dairy cattle. Next (2) the collecting merchant will take the supply of cow's milk from dairy farmers and (3) supply the cows' milk that has been collected by the processor (factory of dadih production).

\section{Analysis of the production of dadih products}

In the supply chain network of dadih products, the dadih product factory plays a role in processing milk that has been collected from milk supplier by fermentation. In general, the activities of the dadih products are: (1) establishing a price agreement for cow's milk, (2) receiving milk supply, (3) processing milk into dadih products, and (4) distributing their products to various retailers. Processing of milk into dadih products is done by three simple steps, namely: (1) fermented milk for two days on the packaging, (2) packaging it with various packaging and size, (3) labeling the packaging. The average unit price for dadih products is between $\mathrm{Rp} 10,000$ to $\mathrm{Rp} 15,000$ per pack.

The dadih products factory will supply its products to prospective retailers to market their products. At the retailer level, there are several activities that occur, among others: (1) offering price agreements to suppliers, (2) receiving supplies from dadih products factories, and (3) marketing finished products to consumers. The price of dadih products that are set for final consumers at this level ranges from $\mathrm{Rp}$ 15,000 to $\operatorname{Rp} 20,000$ per pack.

In the supply chain network of dadih products, the intended consumer is the final consumer in which there are two general activities undertaken, namely (1) buying dadih products at the retailer level and (2) using the product in accordance with their needs for health. The market segmentation of this product is intended for consumers of housewives.

In the supply chain of dadih products, there are four involved actors: dairy farmers $\left(\mathrm{X}_{1}\right)$, collectors $\left(\mathrm{X}_{2}\right)$, curry producers $\left(\mathrm{X}_{3}\right)$, and retailers $\left(\mathrm{X}_{4}\right)$. Every actor in the supply chain has a risk that leads to a product failure probability $\left(\mathrm{P}_{\mathrm{i}} \mathrm{X}\right)$. At this stage, a risk is identified for each supply chain actor as well as possible product failure of any risk. Table 2 shows the identification of supply chain risk of dadih products. Based on the results obtained there are 52 risks from the whole supply chain consisting of 14 risks from dairy farmers, 12 risks on collectors, 15 risks on product cursors, and 11 risks on product retailers. 
Table 2

Results of identification of risk of whey supply

\begin{tabular}{clc}
\hline & \multicolumn{1}{c}{ Variable risk } & $\mathrm{P}_{\mathrm{i}} \mathrm{X}$ \\
\hline 1 & Use of seeds & 0.1740 \\
2 & Ideal location making cages & 0.3510 \\
3 & Treatment of pests & 0.2798 \\
4 & Standardization of pest handling & 0.9139 \\
$:$ & $:$ & $:$ \\
$:$ & $:$ & $:$ \\
5 & Distribution Fee & 0.0374 \\
\hline
\end{tabular}

\subsection{Risk Supply Chain Evaluation of Whey Products}

After identifying the risk then calculated the value added $(\beta x)$ of each supply chain actor with the Hayami method approach. In the calculation used $1000 \mathrm{~kg}$ of cow's milk as a base and produced into $614.93 \mathrm{~kg}$ of dadih products. The result of the percentage of added value with the Hayami approach is shown in Figure 1.

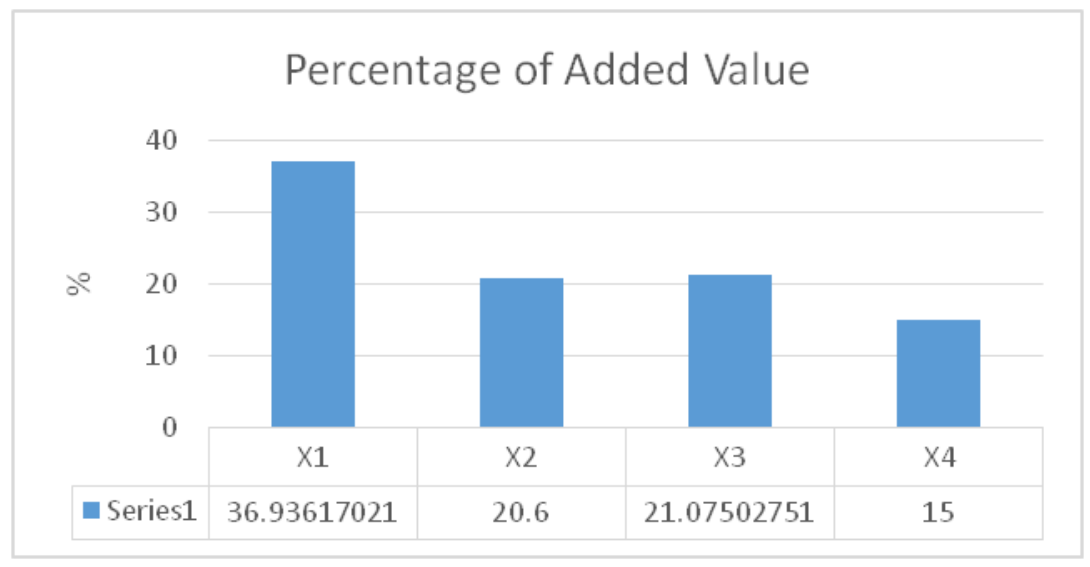

Figure 1

The percentage of the added value of the supply chain of dadih products

Based on the results obtained, it can be seen that dairy farmers $\left(\mathrm{X}_{1}\right)$ has the highest added value in the whole network and followed by the producers of dadih products $\left(\mathrm{X}_{3}\right)$, collectors $\left(\mathrm{X}_{2}\right)$, and retailers $\left(\mathrm{X}_{4}\right)$. After that, we analyze the risk consequence value $\left(\alpha_{\mathrm{x}}\right)$ on each chain actor classified into 4 categories as in Table 3. Then, using the information obtained, it can be calculated risk index of each actor $\left(\mathrm{R}_{\mathrm{ix}}\right)$ as seen in Table 4. Also, it can also be obtained the proportion of the risk of each supply chain dadih product stakeholder saw in Figure 3.

Table 3

Category of the value of consequences

\begin{tabular}{ccc}
\hline Consequence & Information & $\boldsymbol{\alpha}_{\mathbf{x}}$ \\
\hline Vital & No replacement & 1.00 \\
Necessary & Hard to replace & 0.60 \\
Necessary & Easy to replace & 0.30 \\
Desired & Easy to replace & 0.10 \\
\hline
\end{tabular}


Table 4

Results of the risk index of each supply chain actor

\begin{tabular}{lcccc}
\hline $\mathbf{X}$ & $\mathbf{1}$ & $\mathbf{2}$ & $\mathbf{3}$ & $\mathbf{4}$ \\
\hline$\beta_{\mathrm{x}}$ & 0.3694 & 0.2060 & 0.2108 & 0.1500 \\
$\alpha_{\mathrm{x}}$ & 0.600 & 0.300 & 0.300 & 0.300 \\
$\prod_{i=1}^{n}\left(1-P\left(\hat{S}_{x}\right)\right)$ & & & & 1 \\
$\mathbf{R I}_{\mathbf{x}}$ & 0.9999 & 0.9914 & 1 & $\mathbf{0 . 0 4 5}$ \\
\hline
\end{tabular}

\subsection{Supply Chain Risk Management of Dadih Products}

On the risk management of supply chain of dadih products using risk distribution used performance calculation using DEA to produce efficiency used for estimation of risk distribution model. The first performance of all DMUs in each supply chain actor is measured. The evaluated performance consists of 4 input attributes (total cost $\left(\mathrm{I}_{1}\right)$, order fulfillment time $\left(\mathrm{I}_{2}\right)$, product price $\left(\mathrm{I}_{3}\right)$, and risk index $\left(\mathrm{I}_{3}\right)$ )and there is 3 output attributes (quality $\left.\mathrm{O}_{1}\right)$ order fulfillment $\left(\mathrm{O}_{2}\right)$, and the amount of supply $\left(\mathrm{O}_{3}\right)$. Based on the data fed the calculated efficiency of each DMU using the DEA method shown in Table 5. Based on the performance calculation using DEA, then obtained results are used to calculate the optimum price of each actor using the risk distribution model. The model can be seen in Table 6.

Table 5

The results of efficiency measurements using the DEA method

\begin{tabular}{cccccccc}
\hline Unit & $\mathbf{I}_{\mathbf{1}}$ & $\mathbf{I}_{\mathbf{2}}$ & $\mathbf{I}_{\mathbf{3}}$ & $\mathbf{O}_{\mathbf{1}}$ & $\mathbf{O}_{\mathbf{2}}$ & $\mathbf{O}_{\mathbf{3}}$ & $\boldsymbol{\theta}_{\boldsymbol{y}}$ \\
\hline $\mathrm{DMU}_{11}$ & 85 & 40 & 43816 & 0.06 & 2094729 & 6 & 4536 \\
$\mathrm{DMU}_{12}$ & 51 & 93 & 11681 & 0.06 & 2143503 & 7 & 4795 \\
$\mathrm{DMU}_{13}$ & 77 & 82 & 24266 & 0.06 & 2244707 & 6 & 4892 \\
$:$ & $:$ & $:$ & $:$ & $:$ & $:$ & $:$ & $:$ \\
$:$ & $:$ & $:$ & $:$ & $:$ & $:$ & $:$ & $:$ \\
$\mathrm{DMU}_{45}$ & 81 & 88 & 11761 & 0.12 & 1086518 & 7 & 21070 \\
\hline
\end{tabular}

Figure 4 shows the price fluctuations of each DMU on dairy farmers. It can be seen that the optimum price is higher than the current price and it can be seen that the optimum price that should be obtained to maximize the profit of DMU is Rp 5,200, this is due to dairy farmers have a high risk among other actors of the supply chain of other dadih products.

Table 6

Results of the Distribution Model

\begin{tabular}{cccccccccccc}
\hline Stakeholders & Efisiensi & $\mathrm{WR}_{\mathrm{F}}$ & $\mathrm{F}_{\mathrm{y}}$ & $\mathrm{F}_{\mathrm{Fi}}$ & $\rho$ & $\mathrm{I}$ & $\mathrm{FP}_{\mathrm{Fi}}$ & $\begin{array}{c}\text { Standard } \\
\text { total cost }\end{array}$ & $\begin{array}{c}\text { Opt. } \\
\text { price }\end{array}$ & $\begin{array}{c}\text { Current } \\
\text { price }\end{array}$ & \begin{tabular}{c} 
Gap \\
\hline $\mathrm{DMU}_{11}$
\end{tabular} \\
& 1 & 0.567 & 3956102 & $\begin{array}{c}11208 \\
28\end{array}$ & 0 & $\begin{array}{c}11208 \\
28\end{array}$ & 2241656 & 2964000 & 5205 & 4536 & $\begin{array}{c}669 . \\
655 \\
9\end{array}$ \\
$\mathrm{DMU}_{12}$ & 1 & 0.567 & 3956102 & $\begin{array}{c}11208 \\
28\end{array}$ & 0 & $\begin{array}{c}11208 \\
28\end{array}$ & 2241656 & 2964000 & 5205 & 4795 & $\begin{array}{c}410 . \\
655 \\
9\end{array}$ \\
\hline
\end{tabular}




\begin{tabular}{|c|c|c|c|c|c|c|c|c|c|c|c|}
\hline $\mathrm{DMU}_{13}$ & 0.865 & 0.567 & 3956102 & $\begin{array}{c}11208 \\
28\end{array}$ & $\begin{array}{c}0 . \\
1 \\
3 \\
4 \\
7\end{array}$ & $\begin{array}{c}96985 \\
2,4\end{array}$ & 2090680 & 2964000 & 5054 & 4892 & $\begin{array}{c}162 \\
680 \\
4\end{array}$ \\
\hline : & : & : & : & : & : & : & : & : & : & : & : \\
\hline : & : & : & : & : & : & : & : & : & : & : & : \\
\hline $\mathrm{DMU}_{320}$ & 1 & 0.12 & 3956102 & $\begin{array}{c}22758 \\
8,6\end{array}$ & $\begin{array}{l}0 . \\
0 \\
0\end{array}$ & $\begin{array}{c}22758 \\
8,6\end{array}$ & $\begin{array}{c}455177 \\
2\end{array}$ & 10453810 & $\begin{array}{c}1090 \\
8\end{array}$ & 21763 & $\begin{array}{c}- \\
108 \\
54\end{array}$ \\
\hline
\end{tabular}

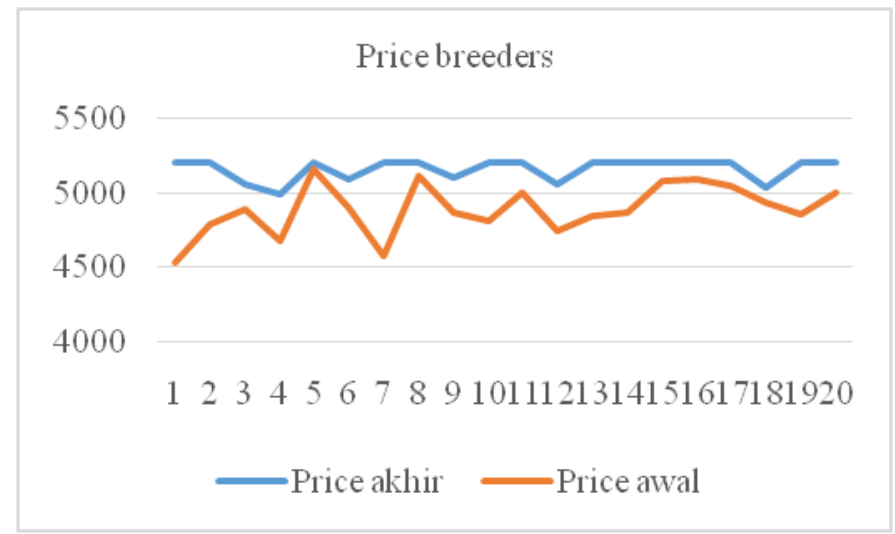

Figure 2

Optimum price for all DMUs on dairy farmers

In Figures 3, 4, and 5, the optimum price shown is lower than the current price, this happens as a result of an unbalanced distribution of risk. In Figure 3, obtained the optimum price to maximize profit is $\mathrm{Rp}$ 5.383. Figure 4 which shows the optimum price for the dadih producer is $\mathrm{Rp} 10,000$ and Figure 5 gives the optimum price for the dadih retailer of $\mathrm{Rp} 11,000$.

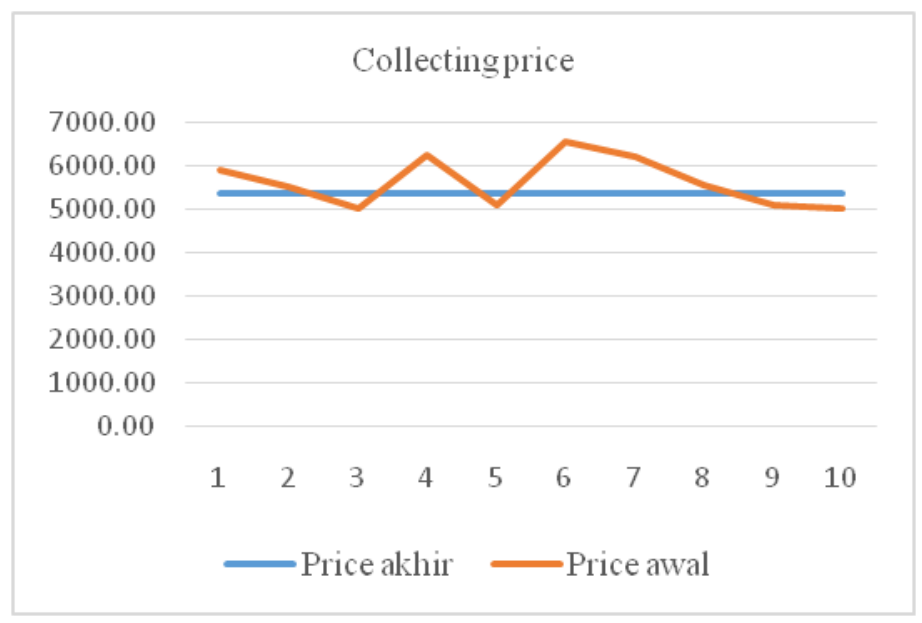

Figure 3

Optimum price for all DMUs in milk collectors 


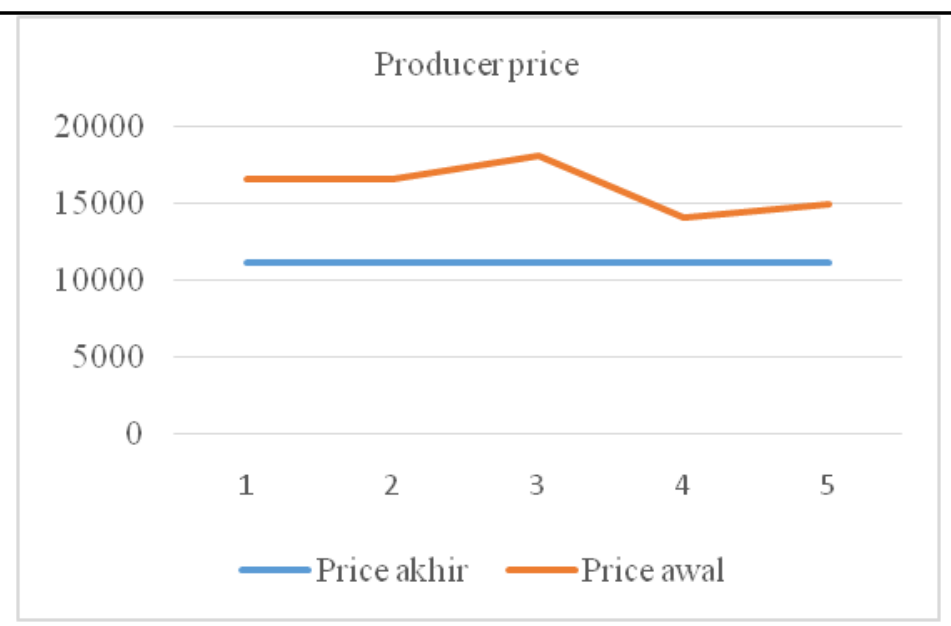

Figure 4

Optimum price of each DMU on the producers of dadih

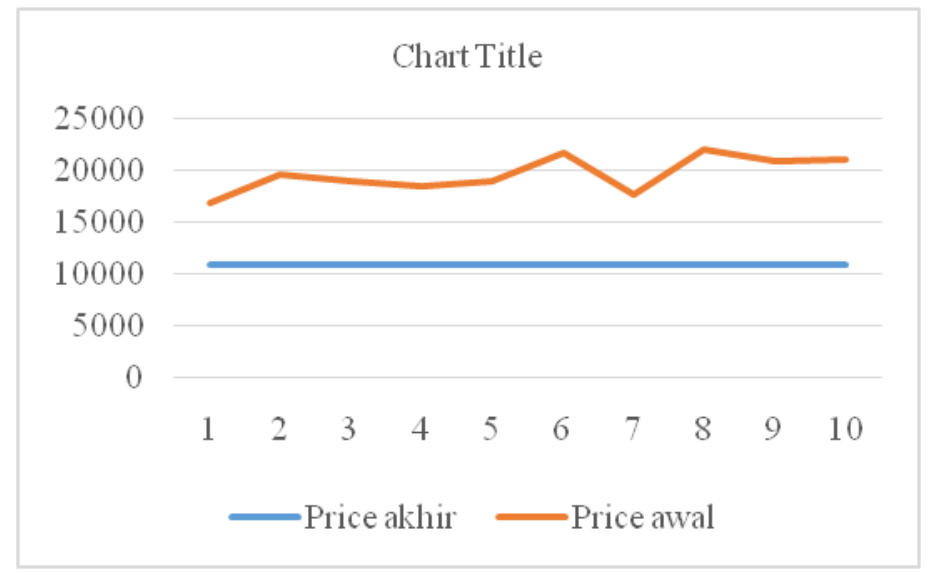

Figure 5

Optimum price of each DMU on retailers

In figures 2, 3, 4 and 5 it can be found that there is significant price fluctuation between DMUs. Then after implementing this model, it can be found that price fluctuations between DMUs become softer. Price fluctuations occur due to the average difference in the efficiency of each DMU. In other words, if the DMU is inefficient, then some incentives are distributed and allocated to other offender networks as a compensation for the distribution of the risk.

\section{Conclusion}

The results of the identification stage, the supply chain of dadih products has 52 risks with risk factors used in each supply chain actors namely supply, process, demand, and price. Based on the evaluation conducted, dairy farmers have the highest risk index compared to other actors that are equal to 0.222 . The DEA method generates the performance of each DMU that will be the input in the risk distribution model. In the risk distribution model, we get the optimum price of each DMU based on the weight of risk and its performance.

\section{Acknowledgement}

Our deep and sincere gratitude is given to God for giving us health and an opportunity to finish this 
writing. Thank you very much to our colleagues who have helped in the research and completed this writing.

\section{References}

[1] Pujawan, I.N. (2005). Supply Chain Management. Surabaya: Guna Widya.

[2] Zsidisin, G.A., Wagner, S.M., Melnyk, S.A., Ragatz, G.L., \& Burns, L.A. (2008). Supply Risk Perceptions and Practices: An Exploratory Comparison of German and US supply Management Professionals," International Journal of Technology. Policy and Management. vol. 8 pp. 401-419.

[3] IRM, A Risk Management Standard. (2001). London: The Association of Insurance and Risk Managers (AIRMIC).

[4] Udayana, I.G.B. (2014). Marketing Risk Management of Palm Oil Based Biodiesel Agroindustry. International Journal on Advanced Science Engineering Information Technology. Vol.4 (2014) No. 1 ISSN: 2088-5334

[5] Delfitriani. (2018). Development of product and packaging appearance design element of dadih using customer personality type with a hybrid Kansei engineering approach. [Thesis]. Bogor: IPB

[6] Badan Pusat Statistik. (2016). Populasi Kerbau Menurut Provinsi 2009-2016. [Internet]. [Accessed 2017 December 17]. Available at http://www.bps.go.id/linkTable Dynamics/view/id/1020.

[7] Zesfin, B.P, \& Zulbardi, M. (2007). Potensi, Kemampuan Produksi dan Reproduksi Kerbau sebagai Penunjang Ketahanan Pangan Masyarakat Sumatera Barat. Prosiding Semnas Hari Pangan Sedunia XXVII. 256-261.

[8] Usmiati, S., Broto, W., \& Setiyanto, H. (2011). Karakteristik Dadih Susu Sapi yang Menggunakan Starter Bakteri Probiotik. JITV. 16(2):141-153.

[9] Culp, C.L. (2002). The art of Risk Management-Alternative risk Transfer, Capital Structure, and the Convergence of Insurance and Capital Markets. New York: John Wiley \& Sons, Inc.

[10] Chapman, R.J. (2006). Enterprise Risk Management: Simple Tools and Techniques. New York: John Wiley $\&$ Sons, Ltd.

[11] Sugitha, I.M. (1995). Dadih Olahan Susu Kerbau Tradisional Minang, Manfaat, Kendala dan Prospeknya dalam Era Industrial Sumatra Barat. Seminar THT dan Gizi Masyarakat. Padang.

[12] Rahman, A, Fardiaz, S., Rahaju, W.P., Suliantari \& Nurwitri, C.C. (1992). Bahan Pengajaran Teknologi Fermentasi Susu. Pusat Antar Universitas Pangan dan Gizi: Institut Pertanian Bogor.

[13] Salminen, S., Ouwehand, A., Benno, Y., \& Lee, Y.K. (1999). Probiotics: How should they be defined? Trends Food Sci. Technol. 10: 107-110. 